\title{
In vitro Potential of Endophytic Fungus Aspergillus terreus (JAS-2) Associated with Achyranthus aspera and Study on its Culture Conditions
}

\author{
Jyoti Goutam ${ }^{1 *}$, Shweta Singh ${ }^{1}$, Ravindra Nath Kharwar ${ }^{1}$ and Vijayakumar Ramaraj ${ }^{2}$ \\ ${ }^{1}$ Laborotary of Mycopathology, Department of Botany, Centre of advance study in Botany, Banaras Hindu University, Varanasi, Uttar Pradesh 221005, India \\ ${ }^{2}$ Department of Microbiology, Sri Ramachandra Medical College \& Research Institute, Porur, Chennai, Tamil Nadu 600116, India
}

*Corresponding author: Jyoti Goutam, Centre of advance study in botany, Banaras Hindu University, Varanasi, Uttar Pradesh 221005, India, Tel: 919452917944; Email: jyoti23biotech@gmail.com

Received date: August 30, 2016; Accepted date: October 10, 2016; Published date: October 17, 2016

Copyright: $\odot 2016$ Goutam J, et al. This is an open-access article distributed under the terms of the Creative Commons Attribution License, which permits unrestricted use, distribution and reproduction in any medium, provided the original author and source are credited.

\begin{abstract}
The present study explores the efficacy of an endophytic fungus from plant Achyranthus aspera, an herb of medicinal importance. Considering limitation of secreted fungal metabolites in terms of biologically active molecules; an endeavour was made to increase the amount of secreted active product. Enhanced secretion of active compound was observed by optimizing different parameters of culture conditions. The fungal culture was isolated from stem of Achyranthus aspera and taxonomically identified as Aspergillus terreus. While analysing it's different in vitro potential, culture metabolites showed antibacterial, antifungal and anti-oxidant activity. In order to increase the yield of crude compound, culture was optimized for different parameters such as carbon and nitrogen sources and extracting solvent. All the optimization was performed based on \% inhibition of bacterial growth when challenged with $10 \mu \mathrm{g} / \mu \mathrm{l}$ metabolite concentration. Among different media used, potato dextrose broth (PDB) and sabouraud's dextrose broth (SDB) proven to be better media for growth of fungus as well as metabolites production. $1 \%$ yeast extract and $4 \%$ dextrose resulted in higher cell inhibition. Ethyl acetate served as good extracting solvent.
\end{abstract}

Keywords: Endophytes; Achyranthus aspera; Antibacterial activity; Antifungal activity; Antioxidant activity

\section{Introduction}

Endophytes are the cryptic factories of diversified metabolites inside plant, synthesising significant compounds of unknown or known medicinal importance. As they are endowed with multitude diversity structure, their physiological functions [1] are being continuously chased for bioactive principles. Study on this endophytic mycoflora revealed that endophytes could be alternative form of drug and by optimizing the culture conditions; activity of bioactive compounds could be enhanced. Endophytically derived compounds such as taxol, cryptocin and isopestacin, justified their significance with respect to their application in human being [2]. But the increased incidence of diseases caused by various bacterial and fungal pathogens forces us to continue our search for newer biometabolites. Apart from identifying newer metabolites, it is important to unveil the structure of already identified biometabolite such as taxol, [3] which revealed the production of host metabolite (host mimetic) from its endophytes. This led to the discovery of different chemical structures such as piperine [4] etc. Since the active molecules represent only $0.0001 \%$ or $1 \mathrm{ppm}$ of total biomass [5], the primary step should be increasing the quantity of bioactive molecules present in metabolites. There are number of reports are available in direction of conditioning cultural parameters by altering the fermentation conditions such as media, $\mathrm{pH}$ and temperature.

In the present study we have demonstrated the optimum culture conditions required for maximum secretion of antibacterial compounds by the endophytic fungal genus JAS-2, which was isolated from Achyranthus aspera, commonly known as latzeera, chichida, apamarga. Considering multiple medicinal properties of this plant such as cytotoxity [6] and wound healing [7], the plant was chosen for isolating biologically active endophytic fungi. Since crude metabolite consists only a meagre amount of bioactive product, it is extremely important to increase the amount of active compound. This could be achieved successfully by optimizing the culture conditions. Globally, it is required to work on diverse fungal metabolomics and its different biotechnological aspects, which would aid in improving the quality and quantity of bioactive molecules.

\section{Materials and Methods}

Isolation and characterization of endophytic Fungi from medicinal plant Achyranthus aspera.

\section{Sampling}

Healthy samples (leaf, stem and root) were collected in sterile polythene bags from botanical garden, at Department of Botany, Banaras Hindu University, Varanasi $(25.5$ N 82.9E, elevation $279 \mathrm{ft} / 85$ $\mathrm{m})$ India and brought to the laboratory in an icebox. Samples were stored at $4^{\circ} \mathrm{C}$ after collection until use.

\section{Surface sterilisation healthy tissues and isolation of endophytic fungi}

In order to screen out only "fungal endophytes" a modified methodology of Dobranic [8] and Schulz [9] was adapted. Briefly, samples were immersed sequentially in $75 \%$ ethanol for $4-5 \mathrm{~min}$ followed by aqueous $2 \%$ sodium hypochlorite for $10 \mathrm{~min}$ and then rinsed in $75 \%$ ethanol for $2 \mathrm{~min}$ or as per requirement of stem/root/leaf tissue. The exposed time length with sterilent could be decided based on tissues strength. Tissues were washed in double distilled sterile water to remove chemical and excess moisture and then blotted on 
sterilized tissue paper. Samples were cut in the dimensions of $0.5 \mathrm{~cm} \times$ $0.5 \mathrm{~cm}$. Six to seven segments of plant tissues were placed on potato dextrose agar (PDA) plate with streptomycin $(100 \mu \mathrm{g} / \mathrm{ml})$, and incubated in a BOD incubator for 21 days at $26 \pm 2^{\circ} \mathrm{C}$. In order to ensure proper surface sterilization, the sterilization protocol was validated using leaf imprint method [9]. The plotted segments were monitored on every alternate day.

\section{Identification of endophyte Aspergillus terreus (JAS-2)}

Isolated endophytic fungus JAS-2 was maintained in potato dextrose agar (PDA) and incubated in BOD incubator. On the basis of macroscopic and microscopical characteristics, the fungus was identified with the help of standard taxonomic manuals $[10,11]$. The microscopic identification was performed with the help of picture was observed by aniline blue stained slide.

\section{Solvent optimization}

Aspergillus terreus JAS-2 was grown at $26^{\circ} \mathrm{C}$ for 21 days to complete its fermentation period. Equal volume of culture broth was extracted individually with three different organic solvents such as hexane, chloroform and ethyl acetate. Concentrated crude extract was checked against different bacterial and fungal pathogens to observe its ability to inhibit the growth by MTT assay.

\section{Evaluation of basal media against bacterial pathogens}

For selecting the best suitable growth medium quantitatively and qualitatively, four different culture media, i.e. potato dextrose broth (PDB), sabouraud's dextrose broth (SDB), malt extract broth (MEB) and czapek dox broth (CZB) were used. The potential of bioactive compound extracted from Aspergillus terreus was assessed by measuring activity of crude extract against targeted bacterial pathogens. Tools to measure inhibitory effect of bacterial pathogen were accessed by MTT assay. The accumulated biomass and bioactive metabolites were measured separately after drying at $70^{\circ} \mathrm{C}$ until a constant weight was obtained.

\section{Effect of carbon and nitrogen sources on biomass and bioactive compound}

To enhance the activity of present compound in crude extract, carbon and nitrogen contents of sabouraud's dextrose broth (SDB) had been replaced with different carbon (starch, sucrose, dextrose and maltose) and nitrogen sources (yeast extract, peptone, beef extract, urea extract and casein) $4 \mathrm{gm} / 100 \mathrm{ml}$ and $1 \mathrm{gm} / 100 \mathrm{ml}$ respectively. Each $250 \mathrm{ml}$ flask containing $100 \mathrm{ml}$ of SDB supplemented with $4 \%$ carbon and $1 \%$ nitrogen sources and SDB without any modification used as control.

\section{Cultivation of culture and extraction of metabolites}

The fresh mycelium grown on PDA plates were inoculated in Erlenmeyer flask of $1000 \mathrm{ml}$ containing $500 \mathrm{ml}$ of PDB medium and incubated for 21 days at $26^{\circ} \mathrm{C}$ in BOD. After 21 days fermented broth of endophyte was filtered and extracted with ethyl acetate. Extracted compounds from solvent were further condensed in vacuum by using rota evaporator.

Determination of antimicrobial activity of Aspergillus terreus JAS-2: Test strains: Different bacterial and fungal pathogens were used as test organisms for antimicrobial assay. The bacterial cultures used were,
Staphylococcus aureus (IMS/GN7), Aeromonas hydrophila (IMS/ GN11), Salmonella typhi (MTCC 3216), Shigella flexneri (IMS/GN1), Escherichia coli (ATCC 25922) and Enterococcus faecalis (ATCC 25923). The fungal pathogens used were Fusarium oxysporum, Bipolaris soronkinana, Aspergillus flavus, Aspergillus niger and Alternaria alternata. All bacterial pathogens were procured from Institute of Medical Science (IMS), and fungal pathogens from Institute of Agricultural Sciences (IAS), Banaras Hindu University, and Varanasi respectively.

In vitro antibacterial bioassay by disk diffusion method: The crude extract from Aspergillus terreus JAS-2 was screened for antibacterial activity by disc diffusion method [12]. Bacterial suspension was made in autoclaved distilled water and bacterial lawn culture was prepared on Mueller Hinton agar plate with sterile cotton swab. Sterile disc impregnated with crude extract at the concentration of $1.0 \mathrm{mg} / \mathrm{disc}$, were placed on the lawn culture and observed for the zone of inhibition after 48 hours. Zone of inhibition was measured using ruler. Ciprofloxacin $(5.0 \mu \mathrm{g} / \mathrm{disc})$ and methanol were used as positive and negative control respectively.

In vitro antifungal activity: Crude metabolites evaluated for antifungal activity, by modified method by Ranware et al. [13]. Briefly, crude metabolite was dissolved in $1 \%$ DMSO to get a concentration of $1.0 \mathrm{mg} / \mathrm{ml}$ and added to $5 \mathrm{ml}$ of sterile potato dextrose broth (PDB) in test tube. Each pathogenic fungal strain having $5 \mathrm{~mm}$ spores cake were inoculated in a test tube and incubated. A separate control was prepared, inoculated with pathogenic fungi without any metabolite. All cultures were incubated for 7 to 15 days at temperature of $26^{\circ} \mathrm{C}$. After 15 days, grown biomass was dried at constant temperature at $70^{\circ} \mathrm{C}$. Inhibitory effect of metabolite grown under the influence of metabolites was calculated using formula.

Fungal growth (C) -Fungal growth after treatment $\times 100=\%$ Reduction in fungal growth Fungal growth (c) Control

\section{In vitro antioxidant assay by DPPH free radical scavenging activity}

Crude metabolites of Aspergillus terreus (JAS-2) was evaluated for antioxidant assay by using DPPH (2, 2-diphyenyl 2 picryl hydrazyl) free radical scavenging method [14]. Since the free radical scavenging activity of any compound is considered to reduce the stable DPPH radical, in order to measure anti-oxidant activity a stock solution of DPPH was prepared $(100 \mathrm{mg} / \mathrm{ml})$ with methanol. Decrease in absorbance of DPPH while increasing the concentration of crude extract was recorded. IC- 50 values were calculated by taking DPPH as negative control. Percentage inhibition activity was calculated by the given formula;

\section{$[(\mathrm{A} 0-\mathrm{A} 1) / \mathrm{A} 0] \times 100$,}

Where $\mathrm{A} 0$ is the absorbance of the control, and A1 is the absorbance of the extract and DPPH. The inhibition curves were prepared and $\mathrm{IC}_{50}$ value calculated. The free radical scavenging activity of the extract, which is based on the scavenging activity of the stable DPPH free radical, was determined by free radical scavenging method. Crude extract $(0.1 \mathrm{ml})$ was added to $3 \mathrm{ml}$ of a $0.004 \%$ methanol solution of DPPH. Absorbance at $517 \mathrm{~nm}$ was determined after $30 \mathrm{~min}$ of incubation period. 
Citation: Goutam J, Singh S, Kharwar RN, Ramaraj V (2016) In vitro Potential of Endophytic Fungus Aspergillus terreus (JAS-2) Associated with Achyranthus aspera and Study on its Culture Conditions. Biol Med (Aligarh) 8: 349. doi:10.4172/0974-8369.1000349

Page 3 of 7

\section{Percentage cell inhibition through MTT assay in each culture conditions}

MTT (3-(4, 5-Dimethylthiazol-2-yl)-2, 5-Diphenyltetrazolium Bromide) assay was introduced by Mossman [13] as a quantitative measurement of mammalian cell survival and their proliferation, and was subsequently used to detect the viability of bacteria under adverse condition. MTT is a yellow tetrazolium salt that is converted into blue formazone by dehydrogenase of live cell. The principle of present assay is the amount of formazone produced is directly proportional to number of live cell. The amount of formazan production, which is detected by measuring $\mathrm{OD}$ at $570 \mathrm{~nm}$, was directly proportional to the initial bacterial concentration and the duration of incubation at $37^{\circ} \mathrm{C}$.

The equal amount $(10 \mu \mathrm{g})$ of crude extract from different culture conditions, were dissolved in DMSO $(10 \mu \mathrm{g} / \mathrm{ml})$ and added to the sterile water glass tubes $(4 \mathrm{ml}) .2 \mu \mathrm{l}$ of test bacterial culture was inoculated in $200 \mu \mathrm{l}$ of sterile Mueller Hinton Broth (MHB). A negative control was prepared by using test bacterium in MuellerHinton broth without any crude extract. An antibiotic $10 \mu \mathrm{g} / \mu \mathrm{l}$ was used as positive control. After incubation period, $60 \mu \mathrm{l}$ MTT solution prepared in phosphate buffer saline (PBS) was added to each tube and incubated for 24 hour. Culture was centrifuged at 10,000 rpm for 5 minutes and absorbance was observed at $570 \mathrm{~nm}$.

Calculation of $\%$ cell inhibition=

OD of Bacterial Growth (C)-OD of Bacterial growth with test sample $\times 100=\%$ Cell viability OD of Bacterial growth (c) Control

Statistical analysis

Data reported is means of triplicate values activity for basal media; optimum solvent, and each carbon and nitrogen sources were studied. Value of data was expressed as mean \pm S.D. from triplicate value. The ANOVA test for unpaired observations between controls and experimental samples for multiple comparisons was conducted to evaluate statistical differences; $p$ values of 0.05 or less were considered statistically significant. The ANOVA test was performed using SPSS (software package used for statistical analysis) version 16 software.

\section{Results and Discussions}

\section{Characterization of endophytic fungus}

Endophytic fungus A. terreus was isolated from stem of medicinal plant Achyranthus aspera (Figure 1a) uprooted from botanical garden BHU Varanasi in the month of June 2014. Initially, the fungal growth was observed as white mycelia colonies on potato dextrose agar (PDA) which turned to brownish yellow after few days (Figures 1b, c). On microscopical observation, conidiophores apex change into globose vesicles on which bi-seriate conidial heads showed the densely attached conidia in chains (Figure 1d). Since it is a thermo tolerant fungus, and its maximum growth reported at $45^{\circ} \mathrm{C}-48^{\circ} \mathrm{C}$ [15], isolation was easy in the month of June.

\section{Screening for antibacterial anti fungal and antioxidant activity}

With the passage of time "Endophytic fungal group" have been proved themselves as one of the major source of antibacterial compounds. Among different groups of endophytic fungi Aspergillus sp and its telomorph contain a large number of species, which have been exploited for various interesting bioactive products [16]. In-vitro screening of antibacterial test by disk diffusion revealed that $S$. aureus, $A$. hydrophila and $E$. faecalis were sensitive to crude metabolite of JAS-2 (Figure 2). Apart from bacteria, fungal isolates such as Alternaria alternata, Bipolaris scrokmiana (MTCC 11857), Fusarium oxysporum, Phytopthora drchlerii var cajai and Aspergillus were also found sensitive for JAS-2 crude metabolites which is tabulated (Table 1). The occurrence of Aspergillus and its different species as endophytes have been reported earlier as an antibacterial, antifungal compounds [17,18]. Apart from Aspergillus species, other genera of endophytic fungi have also exhibited themselves as antibacterial, antifungal and anti-oxidant secreting molecules. It proves that plants are the platform in which endophytes may flourish with its unique biological properties beneficial to human being and plants.

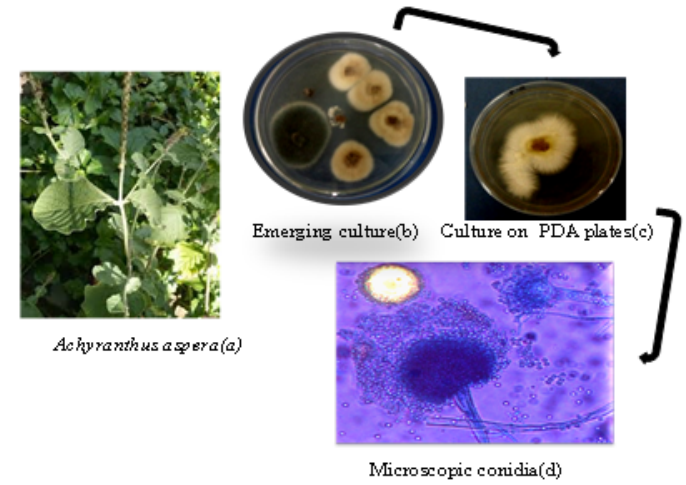

Figure 1: Emergence of endophytic fungus (b, c) (JAS-2) from stem of Achyranthus aspera (a) and its microscopic appearance (d).

\begin{tabular}{|l|l|}
\hline \multicolumn{1}{|c|}{ Pathogenic Fungi } & \multicolumn{1}{c|}{ Inhibition (\%) } \\
\hline Alternaria alternata & 53.3 \\
\hline Fusarium oxysporum & 30.3 \\
\hline Bipolaris soronkiniana & 47.7 \\
\hline Aspergilus flavus & 27.3 \\
\hline Phytopthora sp & 20.7 \\
\hline Clinical human pathogens & ZOI \\
\hline S. aureus & 12 \\
\hline S. typhi & Nil \\
\hline E. faecalis & 10 \\
\hline A. hydrophila & 10 \\
\hline S. flexenei & Nil \\
\hline E. coli & Nil \\
\hline P. aureogenosa & Nil \\
\hline
\end{tabular}

Table 1: Antifungal Inhibition (\%). 
Citation: Goutam J, Singh S, Kharwar RN, Ramaraj V (2016) In vitro Potential of Endophytic Fungus Aspergillus terreus (JAS-2) Associated with Achyranthus aspera and Study on its Culture Conditions. Biol Med (Aligarh) 8: 349. doi:10.4172/0974-8369.1000349

Page 4 of 7

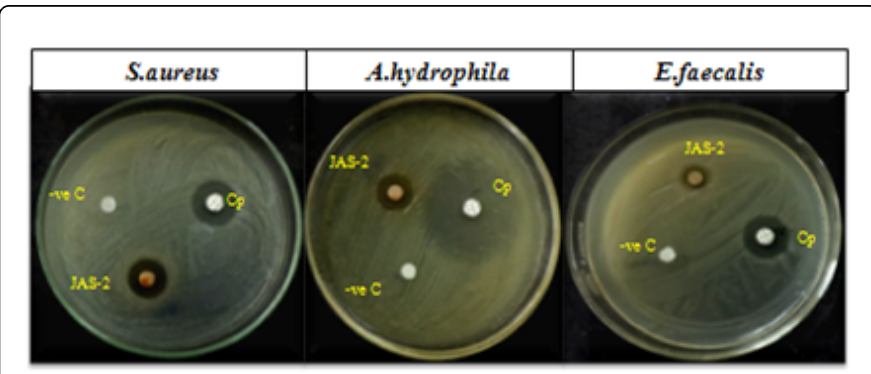

Figure 2: Primary screening of antibacterial compound by disk diffusion assay.

\section{Determination of antioxidant activity}

Free radical scavenging activity of crude metabolite was performed as described by Marwah [12]. In this activity, a varying concentration of crude metabolite dissolved in methanol ranges from $10-100 \mu \mathrm{g} / \mathrm{ml}$, was used. Along with that, ascorbic acid $(10 \mu \mathrm{g} / \mathrm{ml})$ and blank methanol were taken as positive and negative control respectively. There was gradual change of colour in increasing order of metabolite concentration $10-100 \mu \mathrm{g} / \mathrm{ml}$ (Figure 3a). Absorbance is significantly correlated with the concentration of crude extract set in range of concentrations, and graphical interpolation found IC-50 value at 31.4 $\mu \mathrm{g} / \mathrm{ml}$ concentration (Figure $3 \mathrm{~b}$ ). Although crude metabolites showed lower antioxidant activity at $(30 \mu \mathrm{g} / \mathrm{ml})$ as compared to positive control ascorbic acid $(5 \mu \mathrm{g} / \mathrm{ml})$. Extremely higher $\mathrm{IC}_{-50}$ value i.e. $953 \mu \mathrm{g} / \mathrm{ml}$ was reported from endophytes Phoma sp. [19] as compared to the present study. This proves that, antioxidant nature of endophytic fungal metabolites varies among different group of fungi.
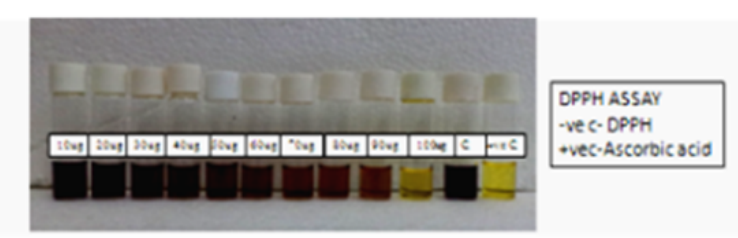

Figure 3a: Primary observation with the change in colour of DPPH (Purple colour).

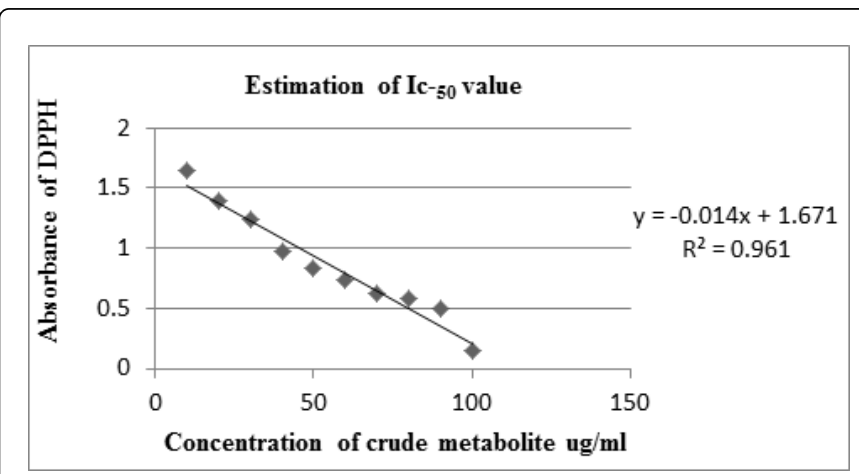

Figure 3b: Calculation of $\mathrm{EC}^{-}{ }_{50}$ value with graphical interpretation.
Many similar results were reported earlier which correlates with our present work. Endophytic fungus Emericella qaudrilineata [20] found it IC- ${ }_{50}$ value of 2, DPPH scavenging at $400 \mu \mathrm{g} / \mathrm{ml}$.

\section{Selection for organic solvent}

Since, selection of suitable solvent system highly depends on the specific nature of the bioactive compound being targeted. Different solvents have ability to extract the bioactive compound from culture broth. Ethyl acetate was recognized as best organic solvent which could be used to extract the bioactive metabolites [21]. Among the three organic solvent used, crude metabolite of JAS-2 extracted using ethyl acetate showed maximum cell inhibition against $A$. hydrophila (41.2\%), S. aureus (45.4\%), E. faecalis (27.3\%) followed by chloroform and hexane respectively (Figure 4 and Table 2). Hexane extract of culture resulted in negligible activity against any pathogenic bacteria, no colour change was observed in hexane with reference to negative control (Deep purple) (Figure 4).

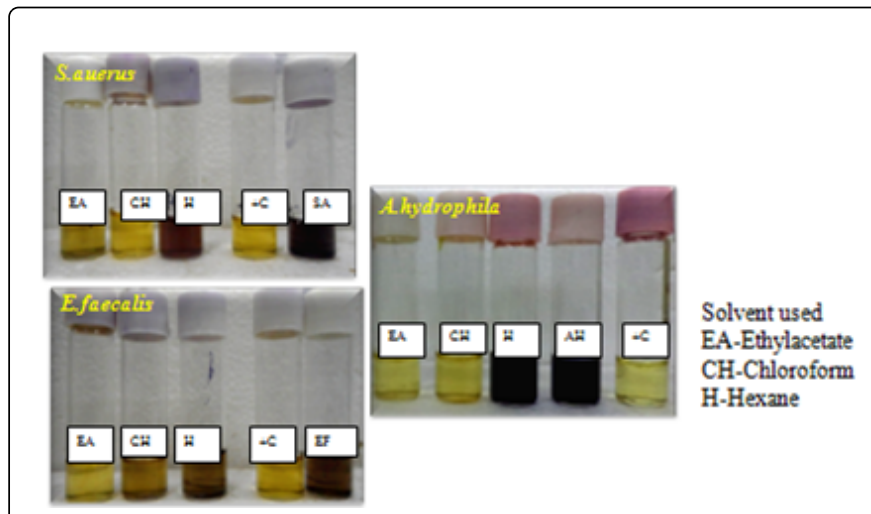

Figure 4: Assessment of coloured formazan produced during solvent optimization.

\begin{tabular}{|c|c|c|c|c|c|}
\hline Solvents & $\begin{array}{c}A . \\
\text { hydrophila }\end{array}$ & $\begin{array}{c}A . \\
\text { hydrophila }\end{array}$ & $\begin{array}{c}A . \\
\text { hydrophila }\end{array}$ & Mean \pm SD & $\begin{array}{c}\% \\
\text { Inhibition }\end{array}$ \\
\hline $\begin{array}{l}\text { Ethyl } \\
\text { Acetate }\end{array}$ & 0.498 & 0.501 & 0.511 & $0.503 \pm 0.00$ & 41.2 \\
\hline Chloroform & 0.614 & 0.605 & 0.601 & $0.607 \pm 0.00$ & 11.6 \\
\hline Hexane & 0.722 & 0.671 & 0.723 & $0.705 \pm 0.02$ & 2 \\
\hline $\begin{array}{l}\text { Positive } \\
\text { Control }\end{array}$ & 0.298 & 0.299 & 0.245 & $0.281 \pm 0.02$ & 61 \\
\hline \multirow[t]{2}{*}{ Control } & 0.775 & 0.679 & 0.711 & $0.722 \pm 0.03$ & \\
\hline & S. aureus & S. aureus & S. aureus & Mean \pm SD & \\
\hline $\begin{array}{l}\text { Ethyl } \\
\text { Acetate }\end{array}$ & 0.361 & 0.328 & 0.351 & $0.347 \pm 0.01$ & 45.4 \\
\hline Chloroform & 0.556 & 0.558 & 0.555 & $0.556 \pm 0.00$ & 12.5 \\
\hline Hexane & 0.623 & 0.651 & 0.603 & $0.626 \pm 0.01$ & 1 \\
\hline $\begin{array}{l}\text { Positive } \\
\text { Control }\end{array}$ & 0.311 & 0.315 & 0.281 & $0.302 \pm 0.01$ & 52.3 \\
\hline \multirow[t]{2}{*}{ Control } & 0.617 & 0.591 & 0.701 & $0.636 \pm 0.04$ & \\
\hline & E. faecalis & E. faecalis & E. faecalis & Mean \pm SD & \\
\hline
\end{tabular}


Citation: Goutam J, Singh S, Kharwar RN, Ramaraj V (2016) In vitro Potential of Endophytic Fungus Aspergillus terreus (JAS-2) Associated with Achyranthus aspera and Study on its Culture Conditions. Biol Med (Aligarh) 8: 349. doi:10.4172/0974-8369.1000349

Page 5 of 7

\begin{tabular}{|l|l|l|l|l|l|}
\hline $\begin{array}{l}\text { Ethyl } \\
\text { acetate }\end{array}$ & 0.487 & 0.488 & 0.432 & $0.469 \pm 0.02$ & 27.73 \\
\hline Chloroform & 0.616 & 0.605 & 0.585 & $0.602 \pm 0.01$ & 7.2 \\
\hline Hexane & 0.678 & 0.611 & 0.648 & $0.646 \pm 0.02$ & 0.4 \\
\hline $\begin{array}{l}\text { Positive } \\
\text { Control }\end{array}$ & 0.342 & 0.341 & 0.312 & $0.332 \pm 0.01$ & 49 \\
\hline Control & 0.617 & 0.681 & 0.651 & $0.650 \pm 0.02$ & \\
\hline
\end{tabular}

Table 2: Inhibition (\%) of bacterial growth by different crude metabolite secreted by JAS-2 extracted with different organic solvent. Data of \% inhibition of bacterial pathogens were statistically analysed by one way Anova were found statistically significant at $5 \%(\mathrm{P}<0.05)$.

\section{Impact of media in isolation of bioactive crude compounds}

Medium optimization is considered as integral part of biopharmaceutical industries with an approach to highest possible product of interest. With respect to fungal physiology, it is important for growth, building of primary metabolites and secondary metabolites. Endophytic fungus Aspergillus terreus was grown in different medium to find the best supporting medium. Best supporting medium was calculated with the help of MTT dye measuring viability of bacterial cells. This work deals with media conditioning optimization, antibacterial activity by MTT assay so that false positive and negative results related to antibacterial could be deleted. All four basal media tested for the production of bioactive metabolites showed significant level of cell inhibition. But SDB and PDB both revealed significant level of cell inhibition against target bacterial pathogens. Sabouraud's dextrose broth (SDB) isolated compounds had shown inhibition $76.5 \%$ against Staphylococcus aureus, $49.8 \%$ against Aeromonas hydrophila and $42.2 \%$ against Enterococcus faecalis (Figure 5 and Table 3 ).

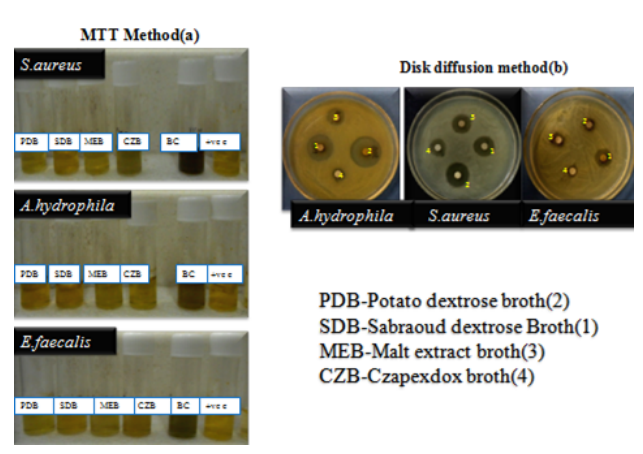

Figure 5: Assessment of coloured formazan produced during basal media selection.

Whereas PDB isolated compounds exhibited little higher inhibition $78.1 \%$ against $S$. aureus and lower inhibition or approximately similar inhibition against $A$. hydrophila $48.6 \%$ and E. faecalis $41.9 \%$ compared to SDB and other media. P-value of OD (optical density) of reduced MTT in tube was found statistically significant at $5 \%$ (Table 3 ). All above results indicates SDB to be the best medium growth of endophytic fungus (JAS-2) as well as production of bioactive metabolite. Earlier studies have been reported in the direction of optimizing basal media, endophytic fungus (Dzf-12) secreted

maximum amount of Palmarumycin $\mathrm{C} 13$ when grown in a modified SDB medium [22].

\begin{tabular}{|c|c|c|c|c|c|}
\hline Media & S. aureus & S. aureus & S. aureus & Mean \pm SD & $\begin{array}{c}\% \\
\text { Inhibition }\end{array}$ \\
\hline PDB & 0.199 & 0.187 & 0.198 & $0.195 \pm 0.00$ & 78.1 \\
\hline SDB & 0.217 & 0.211 & 0.203 & $0.210 \pm 0.00$ & 76.5 \\
\hline MEB & 0.232 & 0.275 & 0.3 & $0.269 \pm 0.02$ & 69.87 \\
\hline \multirow[t]{3}{*}{ CZB } & 0.249 & 0.234 & 0.269 & $0.251 \pm 0.01$ & 70.01 \\
\hline & 0.192 & 0.177 & 0.189 & $0.186 \pm 0.00$ & 79.17 \\
\hline & 0.898 & 0.901 & 0.881 & $0.893 \pm 0.00$ & \\
\hline Media & $\underset{\text { hydrophila }}{A .}$ & $\underset{\text { hydrophila }}{A .}$ & $\underset{\text { hydrophila }}{A .}$ & Mean \pm SD & $\begin{array}{l}\% \\
\text { Inhibition }\end{array}$ \\
\hline PDB & 0.212 & 0.214 & 0.22 & $0.215 \pm 0.00$ & 48.6 \\
\hline SDB & 0.221 & 0.201 & 0.208 & $0.210 \pm 0.00$ & 49.8 \\
\hline MEB & 0.216 & 0.236 & 0.231 & $0.228 \pm 0.00$ & 41.9 \\
\hline CZB & 0.235 & 0.243 & 0.231 & $0.236 \pm 0.00$ & 43.6 \\
\hline $\begin{array}{l}\text { Positive } \\
\text { Control }\end{array}$ & 0.142 & 0.111 & 0.131 & $0.128 \pm 0.00$ & 69.45 \\
\hline Control & 0.412 & 0.394 & 0.452 & $0.419 \pm 0.02$ & \\
\hline Media & E. faecalis & E. faecalis & E. faecalis & Mean \pm SD & $\begin{array}{c}\% \\
\text { Inhibition }\end{array}$ \\
\hline PDB & 0.219 & 0.231 & 0.222 & $0.224 \pm 0.00$ & 41.9 \\
\hline SDB & 0.218 & 0.201 & 0.241 & $0.220 \pm 0.01$ & 42.2 \\
\hline MEB & 0.221 & 0.237 & 0.301 & $0.253 \pm 0.03$ & 34.4 \\
\hline CZB & 0.272 & 0.251 & 0.245 & $0.256 \pm 0.01$ & 33.6 \\
\hline $\begin{array}{l}\text { Positive } \\
\text { Control }\end{array}$ & 0.115 & 0.107 & 0.125 & $0.116 \pm 0.00$ & 70.1 \\
\hline Control & 0.398 & 0.381 & 0.378 & $0.386 \pm 0.00$ & \\
\hline
\end{tabular}

Table 3: Inhibition (\%) of bacterial growth by different crude metabolite secreted by JAS-2 in different media. Data of \%inhibition of bacterial pathogens were statistically analysed by one way Anova were found statistically significant at $5 \%(\mathrm{P}<0.05)$.

\section{Supplement of Carbon and Nitrogen sources in SDB}

It is known that carbon and nitrogen sources are channelled into metabolic machinery of microorganisms so that interesting biotechnological product could be attained. SDB was found to be a best medium to culture JAS-2. Sabouraud's dextrose broth (SDB) is well known defined media which was supplemented with different sources of carbon $4 \%$ and nitrogen $1 \%$. All the media (altered carbon and nitrogen source) have shown efficient antibacterial activity against $S$. aureus, A. hydrophila and E. faecalis illustrated in Table 4 and Figure 6. Medium supplemented with Dextrose and yeast extract as carbon and nitrogen sources, resulted in higher cell inhibitory activity by MTT assay. The inhibitory activity of the crude extract is $54.3 \%$ against Staphylococcus aureus, 51.5\% against Aeromonas hydrophila and $56.06 \%$ against Enterococcus faecalis (Table 4). 
Citation: Goutam J, Singh S, Kharwar RN, Ramaraj V (2016) In vitro Potential of Endophytic Fungus Aspergillus terreus (JAS-2) Associated with Achyranthus aspera and Study on its Culture Conditions. Biol Med (Aligarh) 8: 349. doi:10.4172/0974-8369.1000349

Page 6 of 7

\begin{tabular}{|c|c|c|c|c|c|}
\hline C/N SOU & S. aureus & S. aureus & S. aureus & Mean \pm SD & $\begin{array}{c}\% \\
\text { Inhibition }\end{array}$ \\
\hline Dextrose & 0.414 & 0.378 & 0.394 & $\begin{array}{l}0.395 \quad \pm \\
0.01\end{array}$ & 41.3 \\
\hline Sucrose & 0.415 & 0.511 & 0.527 & $\begin{array}{ll}0.484 & \pm \\
0.04\end{array}$ & 28.18 \\
\hline Maltose & 0.444 & 0.501 & 0.511 & $0.485 \pm 002$ & 28.18 \\
\hline Starch & 0.414 & 0.511 & 0.412 & $\begin{array}{l}0.446 \quad \pm \\
0.04\end{array}$ & 33.97 \\
\hline Peptone & 0.514 & 0.478 & 0.364 & $\begin{array}{l}0.452 \quad \pm \\
0.06\end{array}$ & 32.93 \\
\hline Beef extract & 0.486 & 0.491 & 0.445 & $\begin{array}{ll}0.474 & \pm \\
0.02\end{array}$ & 29.67 \\
\hline $\begin{array}{l}\text { Yeast } \\
\text { extract }\end{array}$ & 0.311 & 0.311 & 0.302 & $\begin{array}{ll}0.308 & \pm \\
0.00\end{array}$ & 54.3 \\
\hline Urea & 0.379 & 0.271 & 0.418 & $\begin{array}{ll}0.356 & \pm \\
0.06\end{array}$ & 47.18 \\
\hline Casein & 0.459 & 0.421 & 0.443 & $\begin{array}{l}0.441 \quad \pm \\
0.01\end{array}$ & 34.56 \\
\hline $\begin{array}{l}\text { Positive } \\
\text { control }\end{array}$ & 0.099 & 0.101 & 0.089 & $\begin{array}{ll}0.096 & \pm \\
0.00\end{array}$ & 85.75 \\
\hline Control & 0.676 & 0.691 & 0.656 & $\begin{array}{l}0.674 \quad \pm \\
0.01\end{array}$ & \\
\hline C/N SOU & $\begin{array}{c}\text { A. } \\
\text { hydrophil } \\
a\end{array}$ & $\begin{array}{c}\text { A. } \\
\text { hydrophil } \\
a\end{array}$ & $\begin{array}{c}\text { A. } \\
\text { hydrophil } \\
a\end{array}$ & Mean \pm SD & $\begin{array}{c}\% \\
\text { Inhibition }\end{array}$ \\
\hline Dextrose & 0.518 & 0.514 & 0.449 & $\begin{array}{ll}0.494 & \pm \\
0.03\end{array}$ & 44.54 \\
\hline Sucrose & 0.615 & 0.709 & 0.617 & $\begin{array}{ll}0.647 & \pm \\
0.04\end{array}$ & 27.21 \\
\hline Maltose & 0.723 & 0.708 & 0.711 & $\begin{array}{l}0.714 \quad \pm \\
0.06\end{array}$ & 19.68 \\
\hline Starch & 0.637 & 0.581 & 0.645 & $\begin{array}{ll}0.621 & \pm \\
0.02\end{array}$ & 30.14 \\
\hline Peptone & 0.512 & 0.632 & 0.621 & $\begin{array}{l}0.588 \quad \pm \\
0.05\end{array}$ & 33.85 \\
\hline Beef extract & 0.525 & 0.521 & 0.524 & $\begin{array}{ll}0.523 & \pm \\
0.00\end{array}$ & 41.16 \\
\hline $\begin{array}{l}\text { Yeast } \\
\text { extract }\end{array}$ & 0.401 & 0.441 & 0.451 & $\begin{array}{l}0.431 \quad \pm \\
0.02\end{array}$ & 51.51 \\
\hline Urea & 0.565 & 0.601 & 0.642 & $\begin{array}{l}0.603 \quad \pm \\
0.03\end{array}$ & 32.28 \\
\hline Casein & 0.632 & 0.607 & 0.612 & $\begin{array}{l}0.617 \quad \pm \\
0.01\end{array}$ & 30.59 \\
\hline $\begin{array}{l}\text { Positive } \\
\text { control }\end{array}$ & 0.181 & 0.141 & 0.101 & $\begin{array}{l}0.141 \quad \pm \\
0.03\end{array}$ & 84.17 \\
\hline Control & 0.849 & 0.858 & 0.961 & $\begin{array}{l}0.889 \quad \pm \\
0.00\end{array}$ & \\
\hline C/N SOU & E. faecalis & E. faecalis & E. faecalis & Mean \pm SD & $\begin{array}{c}\% \\
\text { Inhibition }\end{array}$ \\
\hline
\end{tabular}

\begin{tabular}{|c|c|c|c|c|c|}
\hline Dextrose & 0.502 & 0.501 & 0.471 & $\begin{array}{l}0.491 \quad \pm \\
0.01\end{array}$ & 31.7 \\
\hline Sucrose & 0.519 & 0.513 & 0.515 & $\begin{array}{l}0.516 \quad \pm \\
0.00\end{array}$ & 28.37 \\
\hline Maltose & 0.512 & 0.631 & 0.556 & $\begin{array}{ll}0.566 & \pm \\
0.04 & \end{array}$ & 21.37 \\
\hline Starch & 0.532 & 0.601 & 0.556 & $\begin{array}{l}0.563 \quad \pm \\
0.02\end{array}$ & 21.69 \\
\hline Peptone & 0.615 & 0.604 & 0.564 & $\begin{array}{ll}0.594 & \pm \\
0.02 & \end{array}$ & 17.38 \\
\hline Beef extract & 0.574 & 0.513 & 0.489 & $\begin{array}{ll}0.525 & \pm \\
0.03 & \end{array}$ & 27.26 \\
\hline $\begin{array}{l}\text { Yeast } \\
\text { extract }\end{array}$ & 0.325 & 0.299 & 0.314 & $\begin{array}{l}0.313 \quad \pm \\
0.01\end{array}$ & 56.06 \\
\hline Urea & 0.478 & 0.617 & 0.493 & $\begin{array}{l}0.529 \quad \pm \\
0.06\end{array}$ & 26.42 \\
\hline Casein & 0.502 & 0.615 & 0.401 & $\begin{array}{ll}0.506 & \pm \\
0.08 & \end{array}$ & 29.62 \\
\hline $\begin{array}{l}\text { Positive } \\
\text { control }\end{array}$ & 0.142 & 0.131 & 0.111 & $\begin{array}{l}0.128 \quad \pm \\
0.01\end{array}$ & 82.19 \\
\hline Control & 0.718 & 0.721 & 0.719 & $\begin{array}{l}0.719 \quad \pm \\
0.00\end{array}$ & \\
\hline
\end{tabular}

Table 4: Inhibition (\%) of bacterial growth by different crude metabolite secreted by JAS-2 in different carbon and nitrogen source replaced in Sabouraud's Dextrose Broth (SDB). Data of \%inhibition of bacterial pathogens were statistically analysed by one way Anova were found statistically significant at $5 \%(\mathrm{P}<0.05)$.

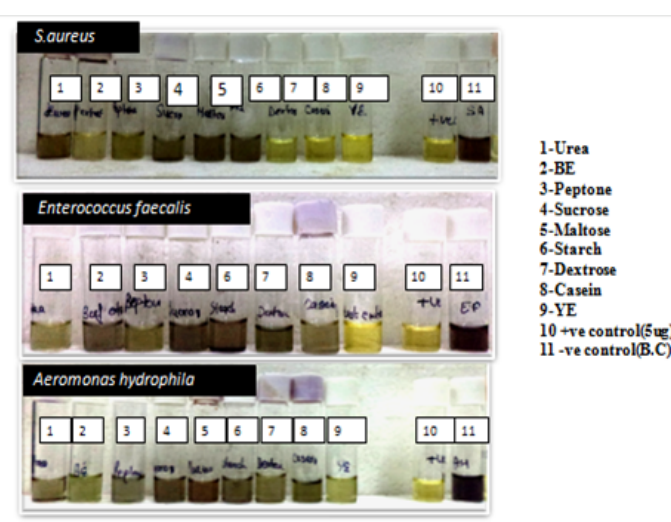

Figure 6: Assessment of coloured formazan produced in carbon and nitrogen sources optimization.

In 1971 Gupta and chaudhary [23] studied the effect of 20 nitrogen sources in antibiotic production followed by Basak and Majumdar [24], who studied the role of carbon and nitrogen sources metabolism in fungal growth. Dextrose is thought to be readily absorbed by microorganisms. With reference to our result a number of microorganisms have elevated their secondary metabolites, when supplemented with yeast extract. In earlier studies on two major metabolites, Tanshinones [25] and Spirobisnaphthalenes [26], yeast extract was found to work as biotic elicitors. 
Considering major experiment of optimization discussed above revealed that endophytes could be a better subject for isolating new bio molecules. The level of these bio molecules could be elevated thereby fulfilling the requirement of pharmaceutically important compound. Medically important compounds could be increase using advance fermentation methods.

\section{Conclusion}

Endophytes have been a great source of bioactive compounds and their effective applications in the field of agriculture, medicine and other industries parts significant importance. Earlier studies had influenced us to show interest on this topic with hope to find a novel bioactive compound. This work has been associated with the study of fungal endophyte JAS-2 that includes isolation of microorganism, optimization of different broth media, impact of carbon and nitrogen sources, in vitro potentials (antibacterial, antifungal and antioxidant) of metabolites and search of leading molecules.

\section{Acknowledgments}

Our research program on fungal endophytes is being supported by University Grants Commission (RGNF), India. Authors are thanking to Prof. Gopal Nath (IMS, BHU) and Prof. R. Chand (IAS, BHU) Varanasi for their support and help in antibacterial and antifungal assays.

\section{References}

1. Gunatilaka AAL (2006) Natural products from plant-associated microorganisms: distribution, structural diversity, bioactivity, and implications of their occurrence. J Nat Prod 69: 509-526.

2. Strobel G, Daisy B (2003) Bioprospecting for microbial endophytes and their natural products. Microbiol Mol Biol Rev 67: 491-502.

3. Stierle A, Strobel G, Stierle D (1993) Taxol and taxane production by Taxomyces andreanae, an endophytic fungus of pacific yew endophytic. Science 260: 214-216.

4. Verma VC, Kharwar RN, Strobel GA (2009) Chemical and functional diversity of natural products from plant associated endophytic fungi. Nat Prod Commun 4: 1511-1532.

5. Cannell RJP (1998) Natural Products Isolation. Springer Science \& Business Media. Human Press Inc, New Jersey, pp. 165-208.

6. Hossain MJ, Khaleda, L, Masudul AM, Chowdhury A, Arifuzzaman A, et al. (2013) Phytochemical screening and evaluation of cytotoxicity and thrombolytic properties of Achyranthes aspera leaf extract. J Phar Biol Sci 6: 30-38.

7. Edwin S, Jarald E, Edwin DL, Jain A, Kinger H, et al. (2008) Wound healing and antioxidant activity of Achyranthes aspera. Pharm Biol 46: 824-828.

8. Dobranic JK, Johnson JA, Alikhan QR (1995) Isolation of endophytic fungi from eastern larch (Larixlaricina) leaves from New Brunswick, Canada. Can J Microbiol 41: 194-198.

9. Schulz B, Guske S, Damman U, Boyle C (1998) Endophyte host interaction II: Defining symbiosis of endophyte host interaction. Symbiosis 25: 212-227.
10. Ainsworth GC, Sparrow FK, Sussman AS (1973) The fungi: an advanced treatise. Academic Press, New York, USA.

11. Barnett HL, Hunter BB (1998) Illustrated genera of imperfect fungi (4thedtn). The American Phytopathological Society, St. Paul, MN, USA.

12. Bauer AW, Kirby WM, Sherries JC, Turck M (1966) Antibiotics susceptibility testing by the standardized single disc method. Am J Clin Pathol 45: 493-496.

13. Ranware A, Singh V, Nimbkar N (2010) In vitro antifungal study of the efficacy of some plant extracts for inhibition of Alternaria carthami fungus. Indian J Exp Biol 1: 384-386.

14. Marwah RG, M OFatope, Mahrooqi RA, Varma BG, et al. (2007) Antioxidant capacity of some edible and wound healing plants in Oman. Food Chem 101: 465-470.

15. Mossman T (1983) Rapid colorimetric assay for cellular growth and survival: application to proliferation and cytotoxicity assays. J Immunol Methods 65: 55-63.

16. Anderson Domsch KH, Games W, Anderson TH (1980) Compendium of soil fungi (2ndedtn) Academic Press, London, UK.

17. Bennett JW, Klich MA (1992) Aspergillus: Biology and Industrial applications.

18. Verma SK, Gond SK, Mishra A, Sharma VK, Kumar J, et al. (2014) Impact of environmental variables on the isolation, diversity and antibacterial activity of endophytic fungal communities from Madhuca indica Gmel. at different locations in India Ann Microbiol 64: 721-734.

19. Fernandes MdRV, SilvaTACe, Pfenning LH, Costa-Neto CMd, Heinrich TA, et al. (2009) Biological activities of the fermentation extract of the endophytic fungus Alternaria alternata isolated from Coffea arabica L. Braz J Pharm Sci 45: 677-685.

20. Goutam J, Sharma VK, Verma SK, Singh DK, Kumar J, et al. (2014) Optimization of cultural condition for enhanced production of bioactive metabolites rich in antimicrobial and antioxidant activities isolated from Emericella quadrilineata an endophyte of Pteris pellucida. J Pure App Microbiol 8: 2059-2073.

21. Jain P, Pundir RK (2011) Effect of fermentation medium, ph and temperature variation on antibacterial soil metabolite production. J Agric Technol 7: 247-269.

22. Zhao J, Wang X, Sun W, Mou Y, Peng Y, et al. (2013) Medium optimization for palmarumycin C13 production in liquid culture of endophytic fungus Berkleasmium sp. Dzf12 using response surface methodology. Elec J Biotechnol 16: 6 .

23. Gupta S, Chaudhary KC (1971) Influence of various nitrogen sources on the production of antibiotic substances by Streptomyces nigrificiens Waksman. Indian. J Mycol Plant Pathol 1: 1-7.

24. Basak K, Mazumdar SK (1973) Utilization of carbon and nitrogen sources by streptomyces kanamyceticus for kanamycin production. Antimicrobes agents chemother 4: 6-10.

25. Zhao J, Zhou L, Wu J (2010) Effects of biotic and abiotic elicitors on cell growth and tanshinone accumulation in Salvia miltiorrhiza cell cultures. Appl Microbiol Biotechnol 87: 137-144.

26. Zhao J, Zheng B, Li Y, Shan T, Mou Y et al. (2011) Enhancement of diepoxin $\zeta$ production by yeast extract and its fractions in liquid culture of berkleasmium-like endophytic fungus Dzf12 from Dioscorea zingiberensis. Molecules 16: 847-856. 